Article

\title{
Effects of Dietary Crude Protein Levels on Fecal Crude Protein, Amino Acids Flow Amount, Fecal and Ileal Microbial Amino Acids Composition and Amino Acid Digestibility in Growing Pigs
}

\author{
Zhenguo Yang *,+, Tianle He ${ }^{+}{ }^{(D}$, Gifty Ziema Bumbie ${ }^{+}$, Hong Hu, Qingju Chen, Changwen Lu \\ and Zhiru Tang * \\ Laboratory for Bio-feed and Molecular Nutrition, College of Animal Science and Technology, \\ Southwest University, Chongqing 400715, China; 18894335705@163.com (T.H.); giftyziema@gmail.com (G.Z.B.); \\ huhong1020@163.com (H.H.); cqj9517@163.com (Q.C.); luchangwen678@163.com (C.L.) \\ * Correspondence: guoguo00002@163.com (Z.Y.); tangzhiru2326@sina.com (Z.T.); Tel.: +86-1568-0923-972 (Z.Y.); \\ +86-1399-6192-900 (Z.T.) \\ + These authors contributed equally to this work.
}

Received: 28 September 2020; Accepted: 9 November 2020; Published: 11 November 2020

Simple Summary: The purpose of this experiment was to evaluate a low protein corn-soybean meal-based diet with the same Lys, Met + Cys, Thr and Trp level as a high protein diet on fecal crude protein (CP), amino acid (AA) flow amount, AA digestibility and fecal and ileal microbial AA composition in growing pigs. Eighteen pigs with an initial body weight of $(30 \pm 1.35) \mathrm{kg}$ were randomly divided into three groups, with six replicates in each group, and fed a corn-soybean meal-based diets with $12 \%, 15 \%$ and $18 \%$ CP levels, respectively. Our aim was to explain whether the addition of four crystalline essential AAs (EAA) to a low diet affected the digestibility of protein-bound NEAA (non-essential amino acid) and EAA and the composition of microbial AA in ileum and feces.

\begin{abstract}
The purpose of this experiment was to evaluate the effects of low protein corn-soybean meal-based diets on fecal CP, amino acid (AA) flow amount, AA digestibility and fecal and ileal microbial AA composition in growing pigs. Eighteen pigs (initial body weight $=30 \pm 1.35$ ) were randomly divided into three groups and fed with basal diets with CP levels of $12 \%, 15 \%$ and $18 \%$, respectively. The Lys, Met + Cys, Thr and Trp level in the 12\% CP and 15\% CP groups is the same as $18 \%$ CP group by the addition of four crystalline Lys, Met + Cys, Thr and Trp to the diet. The results showed that with the decrease of dietary $\mathrm{CP}$ level from $18 \%$ to $12 \%$, the fecal total nitrogen $(\mathrm{N})$, $\mathrm{CP}$ and total AA (TAA) flow amount decreased linearly $(p<0.05)$. Dry matter (DM) digestibility, $\mathrm{CP}$ digestibility, TAA digestibility, essential amino acid (EAA) digestibility and non-essential amino acid (NEAA) digestibility increased linearly with the decrease of dietary $\mathrm{CP}$ concentration from $18 \%$ to $12 \%$. Compared with $18 \% \mathrm{CP}$ group, the flow amount of Asp, Ser, Glu, Gly, Tyr, Val, Leu and Phe in feces of pigs in the $15 \% \mathrm{CP}$ group and $12 \%$ CP group decreased significantly, while the flow amount of Arg in the 15\% CP group was lower than that in the $18 \% \mathrm{CP}$ group and $12 \% \mathrm{CP}$ group. The fecal microbial N and AA of the $15 \% \mathrm{CP}$ group were higher than those of the $18 \% \mathrm{CP}$ and $12 \%$ $\mathrm{CP}$ groups. Fecal TAA flow amount decreased linearly with the decrease of the dietary $\mathrm{CP}$ levels from $18 \%$ to $12 \%$. Fecal TAA and NEAA flow amount also decreased linearly with the decrease of dietary CP level from 18\% to $12 \%$. Except for Glu, Gly, Met, Tyr, Thr and Phe, there were significant differences among the three groups in the composition of 17 kinds of AAs in fecal microorganisms. Among the 17 AA compositions of ileal microorganisms, except Tyr and Lys, the other AAs were significantly different among the three groups $(p<0.05)$
\end{abstract}


Keywords: dietary crude protein levels; essential amino acids; growing pigs; apparent digestibility; composition of fecal and ileal microbial amino acids

\section{Introduction}

In recent years, the environmental pollution caused by nitrogen emission has become more and more serious with the continuous expansion of livestock breeding scales and intensive degrees. At present, the nitrogen emission from livestock and poultry in China is about 500-600 million tons, of which monogastric animals (mainly pigs) account for about $60 \%$ of the total nitrogen emissions. At the same time, China is seriously short of protein resources. In 2019, China's domestic soybeans were about 11 million tons, while imported soybeans were 95.53 million tons. Therefore, to improve protein utilization efficiency and reduce nitrogen emissions has become an urgent scientific problem to be solved.

Nitrogen emission reduction has been studied for a long time, and so far the following nitrogen emission reduction technologies have been formed: preparing dietary protein with ideal AA model [1]; low protein diet technology [2]; increasing the proportion of fermentable carbohydrates in diet [3]; adding feed additives such as enzymes, probiotics and organic acids [4]. Among them, the nitrogen emission reduction effect of low protein diet technology is the most obvious. According to the theory of protein-amino acid nutrition balance, a low protein diet is a diet that can reduce dietary protein levels and nitrogen emissions by adding appropriate kinds and quantities of synthetic AAs without affecting animal production performance and product quality. The practical significance of a low-protein diet is very significant. Studies have shown that for every $1 \%$ reduction of $\mathrm{CP}$ in pig diet, nitrogen emissions can be reduced by $8 \%$ to $10 \%$, and ammonia concentration in pig houses can be reduced by more than $10 \%$ [5]. In the case of supplementation of important EAA, a reduction of $2 \%$ to $3 \%$ in dietary $\mathrm{CP}$ content did not affect the nitrogen deposition or growth performance of pigs [6,7], but the growth performance of pigs was usually negatively affected when the dietary CP content was more than $3 \%[5,8]$. The increasingly serious environmental pollution forces researchers to fundamentally solve the protein and amino acid nutrition of pigs while reducing the nitrogen excretion of pig feces. It is pointed out that reducing the dietary $\mathrm{CP}$ of growing pigs can effectively reduce the nitrogen excretion of pig manure [9]. Reducing $\mathrm{N}$ excretion in swine manure can be effectively accomplished by reducing dietary CP intake. However, reducing the protein concentration of diets, with no supplemental crystalline AA, decreases growth performance and meat and carcass quality [9] and inhibits the activity of the mammalian target of rapamycin (mTOR) and s6 kinase 1 (S6K1), leading to the restriction of protein synthesis [10]. In low-protein diets, the absorption of protein-bound amino acids may be reduced, resulting in impaired animal growth performance if the dietary protein content cannot be further reduced, although the environmental benefits of low-protein diets are significant, the economic benefits are not obvious. Large-scale farms usually take economic benefits as the primary assessment index. Therefore, although the research history of low-protein diet has a history of more than 100 years, it has not been fully promoted in production [11]. In view of this, it is necessary to carry out in-depth study on the regulation mechanism of nitrogen emission reduction of livestock, identify the regulation targets, and develop a low-protein diet with a more efficient effect of nitrogen emission reduction.

The purpose of this experiment was to determine the effects of a low protein corn-soybean-based diet with the same Lys, Met + Cys, Thr and Trp level as high protein diet on fecal CP, AA flow, fecal $\mathrm{CP}, \mathrm{AA}$ digestibility and fecal and ileal microbial AA composition in 30-60 kg growing pigs. Four kinds of crystalline AAs were added to the corn-soybean meal-based diet to reduce the dietary $C P$ concentration to meet the needs of essential AA. In addition, the EAA/NEAA ratio (EAA/NEAA) decreased with the increase of dietary CP concentration. Our aim was to explain whether the addition of four crystalline EAAs to a low-CP diet affected the digestibility of protein-bound NEAA and EAA and the composition of microbial AA in ileum and feces. 


\section{Materials and Methods}

\subsection{Experimental Animals, Design and Diets}

All experimental procedures in this study were approved by Sciences Animal Ethics Committee of Chinese Academy of Sciences (Hunan, China; Ethic approval number: SYXK 2014-0002). Eighteen crossbred barrows (Duroc $\times$ Landrace $\times$ Yorkshire, weighing on average $30 \pm 1.35 \mathrm{~kg}$ ) were randomly allotted to 3 experimental groups in accordance with dietary CP levels of corn-soybean meal-based diets: $12 \%, 15 \%$ and $18 \%$, with six replicates each group and one piglet each replicate. Ingredients and nutrient contents of diets were given in Table 1 and the Lys, Met + Cys, Thr and Trp level in the 12\% CP and $15 \% \mathrm{CP}$ groups is the same as $18 \% \mathrm{CP}$ group by the addition of four crystalline Lys, Met + Cys, Thr and Trp to diet. The trial lasted 30 days. All pigs were kept individually in stainless steel metabolism crates $(1.5 \mathrm{~m} \times 0.5 \mathrm{~m} \times 0.8 \mathrm{~m})$ in an ambient indoor temperature maintained approximately at $24^{\circ} \mathrm{C}$. Natural lighting was used during the experiment. All pig feeds are prepared according to various nutrient requirement recommended by the government (NRC, 2012). Feeding and watering was ad libitum throughout the trial.

\subsection{Measurements and Sampling}

On day 25 to day 30, six pigs each group were chosen to collect feces. Then the pigs were bled and anesthetized by intramuscularly injecting pentobarbital sodium ( $50 \mathrm{mg} / \mathrm{kg} \cdot \mathrm{BW})$. Samples of terminal ileal digesta were collected and put into polythene bags for microbial or chemical analysis. The samples for microbe separation were stored at $4{ }^{\circ} \mathrm{C}$ and for chemical analysis were stored at $-20{ }^{\circ} \mathrm{C}$.

\subsection{Chemical Analysis}

DM was determined by drying to a constant mass in a forced air oven at temperature maintained 95. The previous research methods were used to separate other digested samples by differential centrifugation [12,13]. Firstly, pooled digesta were centrifuged immediately (250×g for 15 min at $4{ }^{\circ} \mathrm{C}$ ), to give a fraction expected to obtain porcine cells and food particles. Secondly, fractions were centrifuged at $14,500 \times g$ for $30 \mathrm{~min}$ at $4{ }^{\circ} \mathrm{C}$, giving precipitates expected to contain microbial cells. $\mathrm{N}$ and ash in feed, feces and microbials were measured by the Leco total combustion method [14]. The AA in feed, feces and microorganisms was measured by a Hitachi Lmur8800 AA automatic analyzer (Hitachi, Ltd., Tokyo, Japan) [15]. Fecal and microbial protein N (PN) and non-protein $\mathrm{N}$ (NPN) were measured by the method of Warren et al. [13].

\subsection{Data Treatment and Statistical Analyses}

Acid insoluble ash (AIA), a kind of endogenous indicator was measured to estimate the apparent digestibility of DM, CP and TAA in feces. The following is the relevant formula: 1-bc/ad. where a denotes the content of DM, CP or AA in diets (\%); b denotes the content of DM, CP or AA in feces (\%); c denotes the content of AIA in diet (\%); d denotes the content of AIA in feces (\%). AA compositions (\%) appertained the content of single AA in TAA.

All results were expressed as mean \pm standard error of mean (SEM). All data were subjected to a one-way analysis of variance using the general linear model (GLM) procedure of SAS 8.2 statistical software (SAS Institute, Inc. Cary, NC, USA) [16] according to a completely randomized one-factorial design. Differences among experimental groups were identified via the Student-Newman-Keuls (SNK) test. A difference was considered to be statistically significant when $p<0.05$. 
Table 1. Ingredients and nutrient contents of diets in 30-60 kg growing pigs (air-dry basis).

\begin{tabular}{|c|c|c|c|c|c|c|c|}
\hline Items & $18 \% \mathrm{CP}$ & $15 \% \mathrm{CP}$ & $12 \% \mathrm{CP}$ & Nutrition Levels & $18 \% \mathrm{CP}$ & $15 \% \mathrm{CP}$ & $12 \% \mathrm{CP}$ \\
\hline Corn & 58.60 & 67.50 & 77.60 & $\mathrm{DE}(\mathrm{MJ} / \mathrm{kg})$ & 14.20 & 14.20 & 14.20 \\
\hline Soy meal & 29.00 & 19.50 & 10.00 & $\mathrm{CP}, \%$ & 18.27 & 15.16 & 12.35 \\
\hline Wheat bran & 7.80 & 6.94 & 5.06 & Lys, \% & 0.97 & 0.97 & 0.94 \\
\hline Soy oil & 1.55 & 2.38 & 3.00 & Met + Cys, \% & 0.57 & 0.56 & 0.55 \\
\hline Monocalcium phosphate & 0.69 & 0.78 & 0.90 & Thr, \% & 0.61 & 0.61 & 0.60 \\
\hline Stone dust & 0.87 & 0.89 & 0.90 & Arg, \% & 1.08 & 0.82 & 0.57 \\
\hline $\mathrm{NaCl}$ & 0.30 & 0.30 & 0.30 & $\operatorname{Trp}, \%$ & 0.17 & 0.17 & 0.17 \\
\hline Vitamin-mineral Premix & 1.00 & 1.00 & 1.00 & His, \% & 0.41 & 0.33 & 0.25 \\
\hline L-Lysine $\mathrm{HCl}$ (Lys) & 0.18 & 0.46 & 0.74 & Phe, \% & 0.77 & 0.62 & 0.46 \\
\hline DL-Methionine (Met) & 0.00 & 0.09 & 0.17 & Val, \% & 0.66 & 0.56 & 0.44 \\
\hline L-Threonine (Thr) & 0.01 & 0.14 & 0.26 & Ile, \% & 0.64 & 0.49 & 0.35 \\
\hline L-Tryptophan (Trp) & 0.00 & 0.02 & 0.07 & Leu, \% & 1.35 & 1.14 & 0.94 \\
\hline \multirow[t]{4}{*}{ Total } & 100.00 & 100.00 & 100.00 & Available $p, \%$ & 0.51 & 0.48 & 0.45 \\
\hline & & & & EAA, \% & 7.00 & 6.04 & 5.03 \\
\hline & & & & NEAA, \% & 9.12 & 7.50 & 5.83 \\
\hline & & & & EAA/NEAA & 0.76 & 0.81 & 0.86 \\
\hline
\end{tabular}




\section{Results}

\subsection{Fecal $N$ and CP Flow and Digestibility}

Feces flow amount and apparent digestibility of $\mathrm{CP}$ and $\mathrm{N}$ of growing pigs were illustrated in Table 2. Feces CP, total N (TN) and NPN flow amounts in growing pigs were affected by the experimental treatments $(p<0.01)$, i.e., greatest in the $18 \% \mathrm{CP}$ group, greater in the $15 \% \mathrm{CP}$ group and lowest in the $12 \% \mathrm{CP}$ group $(p<0.05)$. Fecal PN flow amounts was a highly significant difference among the three experimental groups ( $p<0.01$ ), i.e., lower in the $12 \% \mathrm{CP}$ group than in the $15 \%$ and $18 \% \mathrm{CP}$ group ( $p<0.05)$, but there were no significant differences in feces PN flow amount between the $15 \% \mathrm{CP}$ group and the $18 \% \mathrm{CP}$ group $(p>0.05)$. Feces Total microbial $\mathrm{N}$ and microbial PN flow amount were significantly different among the three experimental groups $(p<0.01)$, i.e., lowest in the $18 \% \mathrm{CP}$ group, greater in the $12 \% \mathrm{CP}$ group and greatest in the $15 \% \mathrm{CP}$ group $(p<0.05)$. Feces apparent digestibility of CP, DM, TN, NPN and PN was also different significantly among the three experimental groups $(p<0.01)$, i.e., greatest in the $12 \% \mathrm{CP}$ group, greater in the $15 \% \mathrm{CP}$ group and lowest in the $18 \% \mathrm{CP}$ group $(p<0.05)$. In addition, there were no significant discrepancies in fecal microbial NPN among the three experimental groups $(p>0.05)$.

Table 2. Feces flow amount and apparent digestibility of crude protein $(\mathrm{CP})$ and $\mathrm{N}$ of growing pigs fed low protein diets.

\begin{tabular}{|c|c|c|c|c|c|}
\hline Items & $18 \% \mathrm{CP}$ & $15 \% \mathrm{CP}$ & $12 \% \mathrm{CP}$ & SEM & $p$-Values \\
\hline \multicolumn{6}{|c|}{ Fecal CP and N flow amount (mg/g DM) } \\
\hline $\mathrm{CP}$ & $245.80^{\mathrm{a}}$ & $228.60^{b}$ & $201.50^{c}$ & 2.70 & $<0.01$ \\
\hline $\mathrm{TN}$ & $39.40^{\mathrm{a}}$ & $36.50^{b}$ & $32.20^{c}$ & 0.43 & $<0.01$ \\
\hline NPN & $4.80^{\mathrm{a}}$ & $3.25^{b}$ & $3.20^{\mathrm{b}}$ & 0.28 & $<0.01$ \\
\hline $\mathrm{PN}$ & $34.60^{\mathrm{a}}$ & $33.30^{\mathrm{a}}$ & $29.10^{b}$ & 0.50 & $<0.01$ \\
\hline Total microbial $\mathrm{N}$ & $5.68^{c}$ & $6.60^{\mathrm{a}}$ & $5.99 \mathrm{~b}$ & 0.07 & $<0.01$ \\
\hline Microbial NPN & 0.64 & 0.70 & 0.64 & 0.02 & 0.14 \\
\hline Microbial PN & $5.05^{c}$ & $5.90^{\mathrm{a}}$ & $5.35^{b}$ & 0.06 & $<0.01$ \\
\hline \multicolumn{6}{|c|}{ Feces apparent digestibility (\%) } \\
\hline $\mathrm{CP}$ & $85.30^{c}$ & $88.10^{\mathrm{b}}$ & $91.00^{a}$ & 0.52 & $<0.01$ \\
\hline $\mathrm{DM}$ & $89.50^{c}$ & $92.00^{\mathrm{b}}$ & $94.60^{\mathrm{a}}$ & 0.41 & $<0.01$ \\
\hline $\mathrm{TN}$ & $85.30^{c}$ & $88.10^{\mathrm{b}}$ & $91.00^{a}$ & 0.52 & $<0.01$ \\
\hline NPN & $83.10^{c}$ & $87.40^{\mathrm{b}}$ & $90.60^{a}$ & 0.93 & $<0.01$ \\
\hline $\mathrm{PN}$ & $97.90^{c}$ & $98.30^{b}$ & $98.70^{a}$ & 0.77 & $<0.01$ \\
\hline
\end{tabular}

a,b,c Values in the same row with different letter superscripts mean significant differences $(p<0.05)$.

\subsection{Feces Total AA (TAA), Essential (EAA) Amino Acids and Non-Essential (NEAA) Flow Amount and Apparent Total Amino Acid Number (TAA) with or without Microbia}

Feces TAA, EAA, NEAA flow amount and apparent digestibility with or without microbia of growing pigs were illustrated in Table 3. Feces TAA, EAA and NEAA flow amounts with or without microbia in growing pigs were affected by the experimental treatments $(p<0.01)$, i.e., greater in the $18 \%$ $\mathrm{CP}$ group than in the $12 \% \mathrm{CP}$ and $15 \% \mathrm{CP}$ groups $(p<0.05)$, but there were no significant differences in feces TAA, EAA and NEAA flow amounts with or without microbia in growing pigs between the $12 \%$ CP group and the $15 \%$ CP group $(p>0.05)$. Digestibility of TAA, EAA and NEAA in feces with microbia and digestibility of EAA in feces without microbial were affected by the experimental treatments $(p<0.01)$, i.e., greater in the $12 \% \mathrm{CP}$ group than in the $15 \% \mathrm{CP}$ and $18 \% \mathrm{CP}$ groups $(p<0.05)$, 
but there were no significant differences in digestibility of TAA, EAA and NEAA in feces with microbia and digestibility of EAA in feces without microbia in growing pigs between the $12 \% \mathrm{CP}$ group and the $15 \%$ CP group $(p>0.05)$. Digestibility of TAA and NEAA in feces without microbia in growing pigs was affected by the experimental treatments $(p<0.01)$, i.e., greatest in the $12 \% \mathrm{CP}$ group, greater in the $15 \% \mathrm{CP}$ group and lowest in the $18 \% \mathrm{CP}$ group $(p<0.05)$. Feces EAA/NEAA flows with or without microbia in growing pigs were affected by the treatments $(p<0.01)$, i.e., greater in the $15 \% \mathrm{CP}$ group than in the $12 \% \mathrm{CP}$ group and the $18 \% \mathrm{CP}$ group $(p<0.05)$. There were no significant differences in feces EAA/NEAA flow in growing pigs between the $12 \% \mathrm{CP}$ group and the $18 \% \mathrm{CP}$ group $(p>0.05)$.

Table 3. Feces Total AA, essentials AA, nonessential AA flow amount (mg/g DM) and apparent digestibility (\%) with or without microbia of growing pigs fed low protein diets.

\begin{tabular}{cccccc}
\hline Items & $\mathbf{1 8 \%} \mathbf{C P}$ & $\mathbf{1 5 \%} \mathbf{C P}$ & $\mathbf{1 2 \%} \mathbf{C P}$ & SEM & $p$-Values \\
\hline Feces with microbes & \multicolumn{1}{c}{} & & & \\
\hline NEAA flow amount & $90.50^{\mathrm{a}}$ & $73.90^{\mathrm{b}}$ & $76.20^{\mathrm{b}}$ & 1.46 & $<0.01$ \\
\hline EAA flow amount & $86.20^{\mathrm{a}}$ & $75.00^{\mathrm{b}}$ & $72.40^{\mathrm{b}}$ & 1.44 & $<0.01$ \\
\hline TAA flow amount & $176.80^{\mathrm{a}}$ & $148.80^{\mathrm{b}}$ & $148.60^{\mathrm{b}}$ & 2.57 & $<0.01$ \\
\hline NEAA digestibility & $92.50^{\mathrm{b}}$ & $93.00^{\mathrm{b}}$ & $94.60^{\mathrm{a}}$ & 0.29 & $<0.01$ \\
\hline EAA digestibility & $90.70^{\mathrm{b}}$ & $90.80^{\mathrm{b}}$ & $92.90^{\mathrm{a}}$ & 0.36 & $<0.01$ \\
\hline TAA digestibility & $91.70^{\mathrm{b}}$ & $92.10^{\mathrm{b}}$ & $93.90^{\mathrm{a}}$ & 0.32 & $<0.01$ \\
\hline EAA/NEAA flow amount & $0.95^{\mathrm{b}}$ & $1.01^{\mathrm{a}}$ & $0.95^{\mathrm{b}}$ & 0.02 & 0.03 \\
\hline Feces without microbes & & & & & $<$ \\
\hline NEAA flow amount & $73.50^{\mathrm{a}}$ & $54.40^{\mathrm{b}}$ & $58.50^{\mathrm{b}}$ & 1.49 & $<0.01$ \\
\hline EAA flow amount & $71.70^{\mathrm{a}}$ & $57.80^{\mathrm{b}}$ & $56.70^{\mathrm{b}}$ & 1.40 & $<0.01$ \\
\hline TAA flow amount & $145.20^{\mathrm{a}}$ & $111.90^{\mathrm{b}}$ & $115.20^{\mathrm{b}}$ & 2.55 & $<0.01$ \\
\hline NEAA digestibility & $93.80^{\mathrm{c}}$ & $94.70^{\mathrm{b}}$ & $95.70^{\mathrm{a}}$ & 0.24 & $<0.01$ \\
\hline EAA digestibility & $92.40^{\mathrm{b}}$ & $93.12^{\mathrm{b}}$ & $94.55^{\mathrm{a}}$ & 0.31 & $<0.01$ \\
\hline TAA digestibility & $93.20^{\mathrm{c}}$ & $94.00^{\mathrm{b}}$ & $95.20^{\mathrm{a}}$ & 0.27 & $<0.01$ \\
\hline EAA/NEAA flow amount & $0.98^{\mathrm{b}}$ & $1.06^{\mathrm{a}}$ & $0.97^{\mathrm{b}}$ & 0.02 & 0.03 \\
\hline a,b,c Values in the same row with different letter superscripts mean significant differences $(p<0.05)$.
\end{tabular}

\subsection{Feces Amino Acids Flow Amount}

Feces Ser, Glu, Ala, Gly, Tyr, Asp, Thr, Cys, Leu and Phe flow amounts were different among the three experimental groups $(p<0.01)$ as illustrated in Table 4 , i.e., compared with the $15 \% \mathrm{CP}$ and $12 \% \mathrm{CP}$ group, it was higher in the $18 \% \mathrm{CP}$ group. However, compared with the $15 \% \mathrm{CP}$ group, it was higher in the $12 \% \mathrm{CP}$ group $(p<0.05)$. There were no significant differences in feces Ser, Glu, Gly, Tyr, Asp, Thr, Leu and Phe flow amounts in growing pigs between the $15 \% \mathrm{CP}$ and $12 \% \mathrm{CP}$ groups $(p>0.05)$. There were no significant differences in feces Pro, Met and His flow amounts in growing pigs among the three treatments $(p>0.05)$. Feces Lys flow amounts were highly significant in their difference among the three experimental groups $(p<0.01)$, i.e., greater in the $15 \% \mathrm{CP}$ group and the $18 \% \mathrm{CP}$ group than in the $12 \% \mathrm{CP}$ group $(p<0.01)$. Feces Leu flow amounts were different among three treatments $(p<0.05)$, i.e., greater in the $18 \% \mathrm{CP}$ group than in the $12 \% \mathrm{CP}$ group and the $15 \%$ $\mathrm{CP}$ group $(p<0.05)$. There were no significant differences in feces Lys flow amounts in growing pigs between the $15 \% \mathrm{CP}$ group and the $18 \% \mathrm{CP}$ group $(p>0.05)$. Feces Ala and Val flow amounts were also very significantly different among the three experimental groups $(p<0.01)$, i.e., greatest in the $18 \%$ $\mathrm{CP}$ group, greater in $12 \% \mathrm{CP}$ group and lowest in $15 \% \mathrm{CP},(p<0.05)$. Feces Arg flow amounts were different among the three experimental groups $(p<0.01)$, i.e., greater in the $12 \% \mathrm{CP}$ group and the $18 \%$ 
$\mathrm{CP}$ group than in the $15 \% \mathrm{CP}$ group $(p<0.05)$. There were no significant differences in feces Arg flow amounts in growing pigs between the $18 \% \mathrm{CP}$ group and $12 \% \mathrm{CP}$ group $(p>0.05)$.

Table 4. Feces amino acids flow amount (mg/g DM) of growing pigs fed low protein diets.

\begin{tabular}{|c|c|c|c|c|c|}
\hline Items & $18 \% \mathrm{CP}$ & $15 \% \mathrm{CP}$ & $12 \% \mathrm{CP}$ & SEM & $p$-Values \\
\hline Ser & $3.30^{\mathrm{a}}$ & $2.80^{b}$ & $2.80^{b}$ & 0.11 & $<0.01$ \\
\hline Glu & $24.00^{a}$ & $20.40^{b}$ & $20.30^{b}$ & 0.62 & $<0.01$ \\
\hline Ala & $19.80^{\mathrm{a}}$ & $15.00^{c}$ & $17.20^{b}$ & 0.51 & $<0.01$ \\
\hline Gly & $15.80^{\mathrm{a}}$ & $12.80^{b}$ & $11.90^{b}$ & 0.42 & $<0.01$ \\
\hline Pro & 9.80 & 8.90 & 10.10 & 0.39 & 0.13 \\
\hline Tyr & $5.90^{a}$ & $5.10^{b}$ & $4.90^{b}$ & 0.21 & 0.01 \\
\hline Asp & $17.90^{\mathrm{a}}$ & $14.00^{b}$ & $13.10^{b}$ & 0.42 & $<0.01$ \\
\hline Thr & $7.20^{\mathrm{a}}$ & $5.60^{b}$ & $4.90^{b}$ & 0.26 & $<0.01$ \\
\hline Val & $12.60^{\mathrm{a}}$ & $9.20^{\mathrm{c}}$ & $10.30^{b}$ & 0.30 & $<0.01$ \\
\hline Cys & $2.60^{a}$ & $2.40^{b}$ & $2.50^{b}$ & 0.05 & 0.01 \\
\hline Met & 3.00 & 2.90 & 2.70 & 0.12 & 0.18 \\
\hline Ile & $10.50^{\mathrm{a}}$ & $9.70^{a b}$ & $8.80^{b}$ & 0.31 & $<0.01$ \\
\hline Leu & $19.00^{\mathrm{a}}$ & $16.90^{\mathrm{b}}$ & $17.10^{b}$ & 0.34 & $<0.01$ \\
\hline Phe & $8.70^{a}$ & $7.70^{\mathrm{b}}$ & $7.60^{b}$ & 0.27 & 0.02 \\
\hline Lys & $8.20^{\mathrm{a}}$ & $7.70^{\mathrm{a}}$ & $6.60^{\mathrm{b}}$ & 0.33 & 0.01 \\
\hline His & 4.10 & 4.30 & 3.70 & 0.18 & 0.09 \\
\hline Arg & $4.50^{\mathrm{a}}$ & $3.60^{b}$ & $4.30^{\mathrm{a}}$ & 0.13 & $<0.01$ \\
\hline
\end{tabular}

\subsection{AAs Digestibility}

The AAs digestibility were illustrated in Table 5. Feces Ser, Glu, Gly, Pro, Tyr, Thr, Ile, Leu, Phe and Lys digestibility were very significantly different among the three experimental groups $(p<0.01)$, i.e., greater in the $12 \% \mathrm{CP}$ group than in the $15 \% \mathrm{CP}$ and $18 \% \mathrm{CP}$ groups $(p<0.05)$, but there were no significant differences in feces Ser, Glu, Gly, Pro, Tyr, Thr, Ile, Leu, Phe and Lys digestibility in growing pigs between the $15 \% \mathrm{CP}$ and $18 \% \mathrm{CP}$ groups $(p>0.05)$. There were no significant differences in feces Arg flow in growing pigs among the three experimental groups $(p>0.05)$. Feces Ala and Val digestibility of pigs in the $15 \% \mathrm{CP}$ group and the $12 \% \mathrm{CP}$ group are higher than in the $18 \% \mathrm{CP}$ group $(p<0.05)$, while there were no significant differences in feces Ala and Val digestibility in growing pigs between the $15 \% \mathrm{CP}$ group and the $12 \% \mathrm{CP}$ group $(p>0.05)$. Feces Cys and His digestibility of pigs in the $12 \% \mathrm{CP}$ group and the $18 \% \mathrm{CP}$ group are higher than in the $15 \% \mathrm{CP}$ group $(p<0.05)$, but there were no significant differences in feces Cys and His digestibility in growing pigs between the $12 \% \mathrm{CP}$ and $18 \%$ CP groups $(p>0.05)$. Feces Met digestibility was very significantly different among these three experimental groups $(p<0.01)$, i.e., greatest in $12 \% \mathrm{CP}$ group, greater in $18 \% \mathrm{CP}$ group and lowest in the $15 \% \mathrm{CP}$ group $(p<0.05)$.

\subsection{The Feces microbial AA Flow Amount}

As shown in Table 6, feces microbial Ser flow amounts were different among the three experimental groups $(p<0.01)$, i.e., greatest in the $15 \% \mathrm{CP}$ group, greater in the $18 \% \mathrm{CP}$ group and lowest in the $12 \%$ CP group $(p<0.05)$. Feces microbial Gly, Ala, Pro, Thr, Ile, TAA and EAA flow amounts were different among the three experimental groups $(p<0.01)$, i.e., greatest in the $15 \% \mathrm{CP}$ group, greater in $12 \%$ and 
lowest in the $18 \%$ CP group $(p<0.05)$. Feces microbial Tyr, Val, Met, Phe and NEAA flow amounts were different among the three experimental groups $(p<0.01)$, i.e., greater in the $15 \% \mathrm{CP}$ group than in the $18 \% \mathrm{CP}$ and $12 \% \mathrm{CP}$ groups $(p<0.05)$, but there were no significant differences in feces microbial Tyr, Val, Met, Phe and NEAA flow in growing pigs between the $12 \% \mathrm{CP}$ and $18 \% \mathrm{CP}$ groups $(p>0.05)$. Feces microbial Asp flows were different among the three experimental groups $(p<0.01)$, i.e., greatest in the $18 \% \mathrm{CP}$ group, greater in the $15 \% \mathrm{CP}$ group and lowest in the $12 \% \mathrm{CP}$ group $(p<0.05)$. Feces microbial Cys flow amounts were different among the three experimental groups $(p<0.01)$, i.e., greater in the $18 \% \mathrm{CP}$ group than in the $15 \% \mathrm{CP}$ and $12 \% \mathrm{CP}$ groups $(p<0.05)$, while there were no significant differences in feces microbial Cys flow amounts in growing pigs between the $12 \% \mathrm{CP}$ group and the $15 \% \mathrm{CP}$ group $(p>0.05)$. Feces microbial Lys and His flow amounts were different among the three experimental groups $(p<0.01)$, i.e., greater in the $15 \% \mathrm{CP}$ and $18 \% \mathrm{CP}$ groups than in the $12 \% \mathrm{CP}$ group $(p<0.05)$. There were no significant differences in feces microbial Lys and His flow in growing pigs between the $18 \% \mathrm{CP}$ group and the $15 \% \mathrm{CP}$. Feces microbial Arg flow amounts were different among the three experimental groups $(p<0.01)$, i.e., greater in the $15 \% \mathrm{CP}$ and $12 \% \mathrm{CP}$ groups than in the $18 \% \mathrm{CP}$ group $(p<0.05)$. There were no significant differences in feces microbial Cys flow amounts in growing pigs between the $12 \% \mathrm{CP}$ group and the $15 \% \mathrm{CP}$ group $(p>0.05)$. There were no significant differences in feces microbial Glu, Leu and EAA/NEAA flow amounts in growing pigs among the three experimental groups $(p>0.05)$.

Table 5. Feces apparent amino acids digestibility (\%) in growing pigs low protein diets.

\begin{tabular}{cccccc}
\hline Items & $\mathbf{1 8 \%} \mathbf{C P}$ & $\mathbf{1 5 \%} \mathbf{C P}$ & $\mathbf{1 2 \%} \mathbf{C P}$ & SEM & $p$-Values \\
\hline Ser & $94.80^{\mathrm{b}}$ & $94.40^{\mathrm{b}}$ & $95.50^{\mathrm{a}}$ & 0.19 & $<0.01$ \\
\hline Glu & $92.00^{\mathrm{b}}$ & $92.40^{\mathrm{b}}$ & $93.90^{\mathrm{a}}$ & 0.38 & $<0.01$ \\
\hline Gly & $85.00^{\mathrm{b}}$ & $86.80^{\mathrm{b}}$ & $89.90^{\mathrm{a}}$ & 0.59 & $<0.01$ \\
\hline Ala & $87.40^{\mathrm{b}}$ & $89.10^{\mathrm{a}}$ & $90.90^{\mathrm{a}}$ & 0.60 & $<0.01$ \\
\hline Pro & $97.10^{\mathrm{b}}$ & $96.90^{\mathrm{b}}$ & $97.60^{\mathrm{a}}$ & 0.16 & 0.01 \\
\hline Tyr & $91.50^{\mathrm{b}}$ & $91.30^{\mathrm{b}}$ & $93.60^{\mathrm{a}}$ & 0.34 & $<0.01$ \\
\hline Asp & $90.00^{\mathrm{c}}$ & $91.50^{\mathrm{b}}$ & $93.00^{\mathrm{a}}$ & 0.39 & $<0.01$ \\
\hline Thr & $91.30^{\mathrm{b}}$ & $92.40^{\mathrm{b}}$ & $94.70^{\mathrm{a}}$ & 0.43 & $<0.01$ \\
\hline Cys & $92.20^{\mathrm{a}}$ & $90.50^{\mathrm{b}}$ & $91.20^{\mathrm{a}}$ & 0.32 & $<0.01$ \\
\hline Val & $88.10^{\mathrm{b}}$ & $90.20^{\mathrm{a}}$ & $90.90^{\mathrm{a}}$ & 0.55 & $<0.01$ \\
\hline Met & $91.70^{\mathrm{b}}$ & $89.00^{\mathrm{c}}$ & $93.20^{\mathrm{a}}$ & 0.44 & $<0.01$ \\
\hline Ile & $88.50^{\mathrm{b}}$ & $88.10^{\mathrm{b}}$ & $91.00^{\mathrm{a}}$ & 0.50 & $<0.01$ \\
\hline Leu & $90.70^{\mathrm{b}}$ & $91.05^{\mathrm{b}}$ & $93.20^{\mathrm{a}}$ & 0.41 & $<0.01$ \\
\hline Phe & $90.20^{\mathrm{b}}$ & $89.50^{\mathrm{b}}$ & $91.50^{\mathrm{a}}$ & 0.48 & 0.03 \\
\hline Lys & $91.50^{\mathrm{b}}$ & $91.20^{\mathrm{b}}$ & $94.60^{\mathrm{a}}$ & 0.43 & $<0.01$ \\
\hline His & $92.40^{\mathrm{a}}$ & $90.30^{\mathrm{b}}$ & $93.30^{\mathrm{a}}$ & 0.49 & $<0.01$ \\
\hline Arg & 96.70 & $97.10^{\mathrm{a}} \mathrm{c}$ & $97.10^{\mathrm{c}}$ & 0.18 & 0.21 \\
\hline Values in the same row with $^{\mathrm{b}}$ & & & & & \\
\hline
\end{tabular}

\subsection{The Feces Microbial AA Composition}

Feces microbial Ser of AA compositions were different among the three experimental groups $(p<0.01)$, i.e., greatest in the $15 \% \mathrm{CP}$ group, greater in the $18 \% \mathrm{CP}$ group, lowest in the $12 \% \mathrm{CP}$ group as illustrated in Table $7(p<0.05)$. Feces microbial Ala, Pro and Ile of AA compositions were different among the three experimental groups $(p<0.01)$, i.e., greater in the $12 \% \mathrm{CP}$ and $15 \% \mathrm{CP}$ groups than in 
the $18 \%$ CP $(p<0.05)$, but there were no significant differences in feces microbial Ala, Pro and Ile of AA compositions in growing pigs between the $12 \% \mathrm{CP}$ and $15 \% \mathrm{CP}$ groups $(p>0.05)$. Feces microbial Asp, Cys, Lys and His of AA compositions were different among the three experimental groups $(p<0.01)$, i.e., greater in the $18 \% \mathrm{CP}$ group than in the $15 \% \mathrm{CP}$ and $12 \% \mathrm{CP}$ groups $(p<0.05)$, but there were no significant differences in feces microbial Asp, Cys, Lys and His of AA composition in growing pigs between the $12 \% \mathrm{CP}$ and $15 \% \mathrm{CP}$ groups $(p>0.05)$. Feces microbial Val of AA compositions were different among three treatments $(p<0.01)$, i.e., greater in the $15 \% \mathrm{CP}$ group than in the $12 \% \mathrm{CP}$ and $18 \% \mathrm{CP}$ groups $(p<0.05)$, but there were no significant differences in microbial Val feces of AA compositions in growing pigs between $12 \% \mathrm{CP}$ group and $18 \% \mathrm{CP}$ group $(p>0.05)$.

Table 6. Feces microbial amino acids flow amount (mg/g DM) of growing pigs fed low protein diets.

\begin{tabular}{cccccc}
\hline Items & $\mathbf{1 8 \%} \mathbf{C P}$ & $\mathbf{1 5 \%} \mathbf{C P}$ & $\mathbf{1 2 \%} \mathbf{C P}$ & $\mathbf{S E M}$ & $p$-Values \\
\hline Ser & $0.58^{\mathrm{b}}$ & $0.84^{\mathrm{a}}$ & $0.50^{\mathrm{c}}$ & 0.02 & 0.08 \\
Glu & $3.99^{\mathrm{a}}$ & $4.49^{\mathrm{a}}$ & 4.20 & 0.14 & $<0.01$ \\
Gly & $2.43^{\mathrm{c}}$ & $2.83^{\mathrm{a}}$ & $2.62^{\mathrm{b}}$ & 0.06 & $<0.01$ \\
Ala & $3.08^{\mathrm{c}}$ & $3.81^{\mathrm{a}}$ & $3.56^{\mathrm{b}}$ & 0.07 & $<0.01$ \\
Pro & $1.38^{\mathrm{c}}$ & $2.11^{\mathrm{a}}$ & $1.98^{\mathrm{b}}$ & 0.04 & $<0.01$ \\
Tyr & $1.23^{\mathrm{b}}$ & $1.41^{\mathrm{a}}$ & $1.20^{\mathrm{b}}$ & 0.04 & $<0.01$ \\
Asp & $4.33^{\mathrm{a}}$ & $4.01^{\mathrm{b}}$ & $3.67^{\mathrm{c}}$ & 0.07 & $<0.01$ \\
Thr & $1.30^{\mathrm{c}}$ & $1.66^{\mathrm{a}}$ & $1.46^{\mathrm{b}}$ & 0.05 & $<0.01$ \\
Cys & $0.38^{\mathrm{a}}$ & $0.28^{\mathrm{b}}$ & $0.26^{\mathrm{b}}$ & 0.03 & 0.01 \\
Val & $1.74^{\mathrm{b}}$ & $2.36^{\mathrm{a}}$ & $1.81^{\mathrm{b}}$ & 0.05 & $<0.01$ \\
Met & $0.58^{\mathrm{b}}$ & $0.69^{\mathrm{a}}$ & $0.55^{\mathrm{b}}$ & 0.02 & 0.02 \\
Ile & $1.38^{\mathrm{c}}$ & $2.35^{\mathrm{a}}$ & $2.03^{\mathrm{b}}$ & 0.04 & $<0.01$ \\
Leu & $3.59^{\mathrm{b}}$ & $3.74^{\mathrm{a}}$ & 3.79 & 0.07 & 0.12 \\
Phe & $1.51^{\mathrm{b}}$ & $1.71^{\mathrm{a}}$ & $1.54^{\mathrm{b}}$ & 0.05 & 0.04 \\
Lys & $1.42^{\mathrm{a}}$ & $1.50^{\mathrm{a}}$ & $1.35^{\mathrm{b}}$ & 0.04 & 0.05 \\
His & $0.90^{\mathrm{a}}$ & $0.91^{\mathrm{a}}$ & $0.78^{\mathrm{b}}$ & 0.03 & 0.01 \\
Arg & $1.72^{\mathrm{b}}$ & $2.19^{\mathrm{a}}$ & $2.17^{\mathrm{a}}$ & 0.06 & $<0.01$ \\
TAA & $31.50^{\mathrm{c}}$ & $36.90^{\mathrm{a}}$ & $33.40^{\mathrm{b}}$ & 0.36 & $<0.01$ \\
NEAA & $17.00^{\mathrm{b}}$ & $19.50^{\mathrm{a}}$ & $17.70^{\mathrm{b}}$ & 0.26 & $<0.01$ \\
EAA & $14.50^{\mathrm{c}}$ & $17.40^{\mathrm{a}}$ & $15.70^{\mathrm{b}}$ & 0.20 & $<0.01$ \\
EAA/NEAA & $0.85^{\mathrm{a}}$ & $0.89^{\mathrm{a}}$ & 0.89 & 0.01 & 0.16 \\
\hline Values in the same row with different letter superscripts mean significant differences $(p<0.05)$
\end{tabular}

Feces microbial Leu of AA compositions were different among the three experimental groups $(p<0.01)$, i.e., greater in the $12 \% \mathrm{CP}$ and $18 \% \mathrm{CP}$ groups than in the $15 \% \mathrm{CP}$ group $(p<0.05)$, but there were no significant differences in feces microbial Leu of AA composition in growing pigs between the $12 \% \mathrm{CP}$ and $18 \% \mathrm{CP}$ groups $(p>0.05)$. Feces microbial Arg of AA compositions were different among the three experimental groups $(p<0.01)$, i.e., greatest in the $12 \% \mathrm{CP}$ group, greater in the $15 \%$ $\mathrm{CP}$ and lowest in the $18 \% \mathrm{CP}(p<0.05)$. There were no significant differences in feces microbial Glu, Gly, Tyr, Thr, Met, Phe, NEAA, EAA and EAA/NEAA of AA composition in growing pigs among the three experimental groups $(p>0.05)$.

\subsection{The Ileal Microbial AA Composition}

Table 8 shows that the ileal microbial Ser, Pro, Val and Ile of AA compositions were different among the three experimental groups $(p<0.01)$, i.e., greater in the $12 \% \mathrm{CP}$ and $15 \% \mathrm{CP}$ group than in $18 \% \mathrm{CP}$ group $(p<0.05)$, but there were no significant differences in feces microbial Ser, Pro, Val and Ile of AA composition in growing pigs between the $12 \% \mathrm{CP}$ group and the $15 \% \mathrm{CP}$ group $(p>0.05)$. The ileal microbial Glu of AA composition was different among the three experimental groups $(p<0.01)$, i.e., greater in the $18 \% \mathrm{CP}$ group than in the $12 \% \mathrm{CP}$ and $15 \% \mathrm{CP}$ groups $(p<0.05)$, but there were no significant differences in feces microbial Glu of AA composition in growing pigs between the $12 \%$ 
$\mathrm{CP}$ group and the $15 \% \mathrm{CP}$ group $(p>0.05)$. The ileal microbial Gly of AA composition was different among the three experimental groups $(p<0.01)$, i.e., greatest in the $15 \% \mathrm{CP}$ group, greater in the $12 \%$ $\mathrm{CP}$ group and lowest in the $18 \% \mathrm{CP}$ group $(p<0.05)$. The ileal microbial Ala of AA composition was different among the three experimental groups $(p<0.01)$, i.e., greatest in the $12 \% \mathrm{CP}$ group, greater in the $15 \% \mathrm{CP}$ group and lowest in the $18 \% \mathrm{CP}$ group $(p<0.05)$. The ileal microbial Asp, Thr and His of AA composition was different among the three experimental groups $(p<0.01)$, i.e., greater in the $12 \%$ $\mathrm{CP}$ and $18 \% \mathrm{CP}$ groups than in the $15 \% \mathrm{CP}$ group $(p<0.05)$. There were no significant difference in feces microbial Asp, Thr and His of AA composition in growing pigs between the $12 \% \mathrm{CP}$ and $18 \% \mathrm{CP}$ groups $(p>0.05)$.

Table 7. Feces microbial amino acids composition (\%) of growing pigs fed low protein diets.

\begin{tabular}{|c|c|c|c|c|c|}
\hline Items & $18 \% \mathrm{CP}$ & $15 \% \mathrm{CP}$ & $12 \% \mathrm{CP}$ & SEM & $p$-Values \\
\hline Ser & $1.83^{\mathrm{b}}$ & $2.28^{a}$ & $1.49^{c}$ & 0.06 & $<0.01$ \\
\hline Glu & 12.64 & 12.16 & 12.54 & 0.34 & 0.57 \\
\hline Gly & 7.70 & 7.68 & 7.83 & 0.18 & 0.80 \\
\hline Ala & $9.8^{\mathrm{b}}$ & $10.3^{a}$ & $10.70^{\mathrm{a}}$ & 0.21 & 0.03 \\
\hline Pro & $4.39^{b}$ & $5.71^{\mathrm{a}}$ & $5.89^{\mathrm{a}}$ & 0.12 & $<0.01$ \\
\hline Tyr & 3.91 & 3.83 & 3.59 & 0.12 & 0.11 \\
\hline Asp & $13.7^{\mathrm{a}}$ & $10.9^{b}$ & $11.0^{\mathrm{b}}$ & 0.19 & $<0.01$ \\
\hline Thr & 4.13 & 4.51 & 4.36 & 0.12 & 0.12 \\
\hline Cys & $1.20^{\mathrm{a}}$ & $0.77^{b}$ & $0.76^{b}$ & 0.08 & $<0.01$ \\
\hline Val & $5.53^{b}$ & $6.39^{a}$ & $5.44^{b}$ & 0.14 & $<0.01$ \\
\hline Met & 1.85 & 1.86 & 1.64 & 0.06 & 0.04 \\
\hline Ile & $4.37^{b}$ & $6.38^{a}$ & $6.06^{\mathrm{a}}$ & 0.13 & $<0.01$ \\
\hline Leu & $11.4^{\mathrm{a}}$ & $10.1^{b}$ & $11.30^{\mathrm{a}}$ & 0.23 & $<0.01$ \\
\hline Phe & 4.78 & 4.63 & 4.61 & 0.15 & 0.66 \\
\hline Lys & $4.50^{\mathrm{a}}$ & $4.08^{b}$ & $4.04^{b}$ & 0.12 & 0.03 \\
\hline $\mathrm{His}$ & $2.83^{a}$ & $2.47^{b}$ & $2.32^{b}$ & 0.09 & $<0.01$ \\
\hline Arg & $5.44^{\mathrm{c}}$ & $5.93^{b}$ & $6.45^{\mathrm{a}}$ & 0.16 & $<0.01$ \\
\hline TAA & 100.00 & 100.00 & 100.00 & 0.00 & 1.00 \\
\hline NEAA & 54.00 & 52.80 & 53.00 & 0.42 & 0.16 \\
\hline EAA & 46.00 & 47.10 & 47.00 & 0.42 & 0.16 \\
\hline EAA/NEAA & 0.85 & 0.89 & 0.89 & 0.01 & 0.16 \\
\hline
\end{tabular}

$\mathrm{a}, \mathrm{b}, \overline{\mathrm{c}}$ Values in the same row with different letter superscripts mean significant differences $(p<0.05)$.

The ileal microbial Cys and Met of AA composition was different among the three experimental groups $(p<0.01)$, i.e., greatest in the $18 \% \mathrm{CP}$ group, greater in the $12 \% \mathrm{CP}$ group and lowest in the $15 \%$ CP group $(p<0.05)$. The ileal microbial Leu of AA composition was different among the three experimental groups $(p<0.01)$, i.e., greater in the $15 \% \mathrm{CP}$ and $18 \% \mathrm{CP}$ groups than in the $12 \% \mathrm{CP}$ group $(p<0.05)$. There were significant differences in feces microbial Leu of AA composition in growing pigs between the $18 \%$ CP group and the $15 \%$ CP group $(p<0.05)$. The ileal microbial Phe, EAA and EAA/NEAA of AA composition was different among the three experimental groups $(p<0.01)$, i.e., greatest in the $18 \% \mathrm{CP}$ group and lowest in the $12 \% \mathrm{CP}$ group $(p<0.05)$. The ileal microbial NEAA of AA composition was different among the three experimental groups $(p<0.01)$, i.e., greater in the $12 \% \mathrm{CP}$ group than in the $15 \% \mathrm{CP}$ and $18 \% \mathrm{CP}$ groups $(p<0.05)$. There were no significant differences in feces microbial NEAA of AA composition in growing pigs between the $15 \% \mathrm{CP}$ and $18 \% \mathrm{CP}$ groups $(p>0.05)$. There were no significant differences in feces microbial Tyr and Lys of AA composition in growing pigs among the three experimental groups $(p>0.05)$. The ileal microbial Arg of AA composition was different among the three experimental groups $(p<0.01)$, i.e., greatest in the $15 \% \mathrm{CP}$ group, greater in the $12 \% \mathrm{CP}$ group and lowest in the $18 \% \mathrm{CP}$ group $(p<0.05)$. 
Table 8. Ileal microbial amino acids composition (\%) of growing pigs fed low protein diets.

\begin{tabular}{cccccc}
\hline Items & $\mathbf{1 8 \%} \mathbf{C P}$ & $\mathbf{1 5 \%} \mathbf{C P}$ & $\mathbf{1 2 \%} \mathbf{C P}$ & $\mathbf{S E M}$ & $p$-Values \\
\hline Ser & $3.23^{\mathrm{b}}$ & $4.03^{\mathrm{a}}$ & $4.36^{\mathrm{a}}$ & 0.12 & $<0.01$ \\
Glu & $12.84^{\mathrm{a}}$ & $9.74^{\mathrm{b}}$ & $9.04^{\mathrm{b}}$ & 0.25 & $<0.01$ \\
Gly & $4.93^{\mathrm{c}}$ & $6.54^{\mathrm{a}}$ & $5.59^{\mathrm{b}}$ & 0.12 & $<0.01$ \\
Ala & $6.00^{\mathrm{c}}$ & $8.28^{\mathrm{b}}$ & $8.96^{\mathrm{a}}$ & 0.18 & $<0.01$ \\
Pro & $4.85^{\mathrm{b}}$ & $6.80^{\mathrm{a}}$ & $6.30^{\mathrm{a}}$ & 0.19 & $<0.01$ \\
Tyr & 3.50 & 3.97 & 3.64 & 0.19 & 0.24 \\
Asp & $11.8^{\mathrm{a}}$ & $8.8^{\mathrm{b}}$ & $11.8^{\mathrm{a}}$ & 0.23 & $<0.01$ \\
Thr & $3.26^{\mathrm{a}}$ & $2.26^{\mathrm{b}}$ & $3.01^{\mathrm{a}}$ & 0.12 & $<0.01$ \\
Cys & $2.57^{\mathrm{a}}$ & $1.36^{\mathrm{c}}$ & $1.57^{\mathrm{b}}$ & 0.05 & $<0.01$ \\
Val & $5.31^{\mathrm{b}}$ & $6.94^{\mathrm{a}}$ & $6.88^{\mathrm{a}}$ & 0.17 & $<0.01$ \\
Met & $3.95^{\mathrm{a}}$ & $2.24^{\mathrm{c}}$ & $3.14^{\mathrm{b}}$ & 0.15 & $<0.01$ \\
Ile & $5.29^{\mathrm{b}}$ & $6.80^{\mathrm{a}}$ & $6.75^{\mathrm{a}}$ & 0.28 & $<0.01$ \\
Leu & $11.8^{\mathrm{a}}$ & $11.8^{\mathrm{a}}$ & $10.6^{\mathrm{b}}$ & 0.23 & $<0.01$ \\
Phe & $7.75^{\mathrm{a}}$ & $6.91^{\mathrm{b}}$ & $5.77^{\mathrm{c}}$ & 0.12 & $<0.01$ \\
Lys & $4.30^{\mathrm{a}}$ & $4.80^{\mathrm{a}}$ & 4.67 & 0.32 & 0.52 \\
His & $4.38^{\mathrm{a}}$ & $3.71^{\mathrm{b}}$ & $4.61^{\mathrm{a}}$ & 0.19 & 0.01 \\
Arg & $4.22^{\mathrm{b}}$ & $5.00^{\mathrm{a}}$ & $3.26^{\mathrm{c}}$ & 0.15 & $<0.01$ \\
TAA & 100.00 & 100.00 & 100.00 & 0.00 & 1.00 \\
NEAA & $43.70^{\mathrm{b}}$ & $44.20^{\mathrm{b}}$ & $46.10^{\mathrm{a}}$ & 0.23 & $<0.01$ \\
EAA & $52.80^{\mathrm{a}}$ & $51.80^{\mathrm{b}}$ & $50.30^{\mathrm{c}}$ & 0.26 & $<0.01$ \\
EAA/NEAA & $1.21^{\mathrm{a}}$ & $1.17^{\mathrm{b}}$ & $1.09^{\mathrm{c}}$ & 0.01 & $<0.01$ \\
\hline a,b,c Values in the same row with different letter superscripts mean significant differences $(p<0.05)$.
\end{tabular}

\section{Discussion}

\subsection{Fecal N Excretion}

Livestock and poultry excreta are important sources of environmental $\mathrm{N}$ pollution. In feeding and management, it has become an effective way to reduce nitrogen emissions by reducing the amount of protein raw materials to reduce dietary protein levels, and then by adding synthetic AA, to meet animal AA needs of low-protein diets [16]. Compared to feeding them the $18 \% \mathrm{CP}$ diet, fecal $\mathrm{N}$ losses decreased by $7.4 \%$ and $18.3 \%$ when feeding the $15 \%$ and $12 \%$ (protein-free) CP diet, respectively. Our values are lower than those reported previously. Gloaguen et al. [17] pointed out that dietary protein levels decreased from $20 \%$ to $17 \%$, with an average reduction of 1 percentage point, and total nitrogen emissions decreased by $8.04 \%$. At the same time, with the decrease of dietary protein levels, $\mathrm{N}$ intake, $\mathrm{N}$ uptake and $\mathrm{N}$ deposition decreased, while $\mathrm{N}$ apparent utilization efficiency and biological potency increased. In addition, previous study has shown that $\mathrm{N}$ excretion was reduced by $10 \%$ and $40 \%$ when decreasing dietary CP levels from $15 \%$ to $6 \%$ in growing pigs [18]. In the present study, our greatest contribution to decreasing the fecal $\mathrm{N}$ losses when reducing $\mathrm{CP}$ concentration from $18 \%$ to $12 \%$ is protein $\mathrm{N}$ origin. We also found that feces microbial $\mathrm{N}$ of growing pigs had no obvious change among the $12 \%, 15 \%$ and $18 \% \mathrm{CP}$ diets; therefore, microbial $\mathrm{N}$ in feces is not a principal factor to reduce total N-losses. However, other research suggests that Bacterial N, combined with ammonia and urea $\mathrm{N}$, accounted for approximately $61 \%$ of total nitrogenous losses in pigs which were fed free protein diets or casein diets [13]. Dietary manipulation to reduce $\mathrm{NH}_{3}$ emission seems highly effective for realistic and efficient practice to reduce $\mathrm{NH}_{3}$ emission throughout the process from feeding the animal to spreading the fertilizer [19]. Dietary regulation to decrease $\mathrm{NH}_{3}$ emissions seems to be a highly effective method to cut back on $\mathrm{NH}_{3}$ emissions. We also know that reducing dietary CP levels is one effective way to decrease ammonia emitted from pigs houses in industry [20]. 


\subsection{AA Digestibility}

Added essential crystalline AA to low-protein diet can not only increase AA digestibility and reduce AA excretion, but also provide a better balance of AA absorption for the whole intestine by decreasing the competition of intestinal epithelial cells for AA transport [18]. The research showed that adding crystalline AA to diets could improve the digestible energy, metabolizable energy and net energy of growing pigs [21]. Similarly, adding crystalline AA to low-protein diets can improve performance and carcass traits of late-breeding sows [16]. Other studies have shown that adding branched chain AA to low-protein diets can improve the growth performance in pigs to a level similar to that of adequate protein diets [22]. In addition, crystalline AA can provide growth requirements for broilers in low-protein diets [23]. In conclusion, added EAA to low-protein diet can make up for the problem of protein deficiency, and even improve animal production performance and lipid metabolism.

\subsection{Microbial AA Composition}

The present study indicated that the effects of dietary $\mathrm{N}$ substrates on ileal microbial AA composition were more significant than in feces. Ileal microbial EAA and NEAA compositions were affected by dietary AA composition, while fecal microbial EAA and NEAA compositions were not affected by dietary AA composition. This is related to the different microbiome composition from anterior to posterior [24]. Up until now, very little research has addressed the microbial AA composition of pigs. Yet, the decomposition and synthesis of $\mathrm{N}$ and AA in intestinal microflora were very active. Previous studies have shown that NEAA added to a low-protein Thr-deficient diet can improve the utilization of these AAs for protein deposition in young pigs [25]. Branched chain AA, Lys and Phe, synthesized by swine intestinal bacteria with intestinal fistula, can be absorbed in the small intestine and large intestine [26-28]. In addition, prior research has suggested that a carbohydrate to nitrogenous compound ratio in the large intestine is an determinant factor of microbial metabolism and gut barrier function in the colon [29]. These findings will be beneficial to enhancing our understanding of the fact that microbe-related secondary bile acid metabolism may mediate the interplay between intestinal barrier functions and microbes.

\section{Conclusions}

In conclusion, we had direct implications for reducing dietary $\mathrm{CP}$ levels from $18 \%$ to $12 \%$, including a decreased fecal $\mathrm{N}$ excretion, and a principal factor to reducing total $\mathrm{N}$ losses in feces was dietary $\mathrm{N}$ except for microbial N. Microbial EAA and NEAA composition in ileum was affected by the AA composition in growing pigs' diets, while dietary AA composition had no effects on the composition of microbial EAA and NEAA in feces.

Author Contributions: Conceptualization, Z.Y., and Z.T.; Data curation, Z.Y. and T.H.; Formal analysis, Q.C., H.H., and Z.Y.; Funding acquisition, Z.Y., and Z.T.; Investigation, G.Z.B. and T.H.; Methodology, Z.Y. and Z.T.; Project administration, Z.Y. and Z.T.; Resources, Z.Y. and Z.T.; Software, C.L.; writing—original draft, G.Z.B., T.H. and Z.Y.; writing - review and editing, Z.Y. and T.H. All authors have read and agreed to the published version of the manuscript.

Funding: The work was financially supported by National Natural Science Foundation of China (31772610, 31902167), Chongqing Natural Science Foundation (Basic Research and Frontier Exploration Special Project) General Project (Grant No. cstc2019jcyj-msxmX0524), National Science Foundation for Post-doctoral Scientists of China (Grant No. 2018M640895), Special Funding for Postdoctoral Research Projects in Chongqing (Grant No. XMT 2081061), Chongqing key innovation project for overseas students (cx2017024), Excellent Youth Exchange Program of China Association for Science and Technology in 2019 (2019(293)-98), National Key R\&D Program of China (2018YFD0501000), National Basic Research Program of China (2013CB127303), China Scholarship Council (201508505170).

Conflicts of Interest: The authors declare no conflict of interest. 


\section{References}

1. Chung, T.K.; Baker, D.H. Ideal amino acid pattern for 10-kilogram pigs. J. Anim. Sci. 1992, 10, $3102-3111$. [CrossRef] [PubMed]

2. Boujendar, S.; Reusens, B.; Merezak, S.; Ahn, M.-T.; Arany, E.; Hill, D.; Remacle, C. Taurine supplementation to a low protein diet during foetal and early postnatal life restores a normal proliferation and apoptosis of rat pancreatic islets. Diabetologia 2002, 45, 856-866. [CrossRef] [PubMed]

3. Shriver, J.A.; Carter, S.D.; Sutton, A.L.; Richert, B.T.; Senne, B.W.; Pettey, L.A. Effects of adding fiber sources to reduce d-crude protein, amino acid-supplemented diets on nitrogen excretion, growth performance, and carcass traits of finishing pigs. J. Anim. Sci. 2003, 81, 492-502. [CrossRef] [PubMed]

4. Puiman, P.; Stoll, B.; Molbak, L.; De Bruijn, A.; Schierbeek, H.; Boye, M.; Boehm, G.; Renes, I.; Van Goudoever, J.; Burrin, D. Modulation of the gut microbiota with antibiotic treatment suppresses whole body urea production in neonatal pigs. Am. J. Physiol Cell Physiol. 2013, G300-G310. [CrossRef]

5. Kerr, B.J.; Mckeith, F.K.; Easter, R.A. Effect on performance and carcass characteristics of nursery to finisher pigs fed reduced crude protein, amino acid-supplemented diets. J. Anim. Sci. 1995, 73, 433-440. [CrossRef]

6. Rotz, C. Management to reduce nitrogen losses in animal production. J. Anim. Sci. 2004, 82, E119-E137. [CrossRef]

7. Jin, J.P.; Zhang, L.P.; Jia, J.L.; Chen, Q.; Yuan, Z.; Zhang, X.Y.; Sun, W.B.; Ma, C.M.; Xu, F.F.; Zhan, S.J.; et al. Effects of Maternal Low-Protein Diet on Microbiota Structure and Function in the Jejunum of Huzhu Bamei Suckling Piglets. Animals 2019, 9, 713. [CrossRef]

8. Figueroa, J.L.; Lewis, A.J.; Miller, P.S.; Fischer, R.L.; Gómez, R.S.; Diedrichsen, R.M. Nitrogen metabolism and growth performance of gilts fed standard corn-soybean meal diets or low-crude protein, amino acid-supplemented diets. J. Anim. Sci. 2002, 80, 2911-2919. [CrossRef]

9. Kumar, A.; Bhar, R.; Mandal, A.B.; Mendiratta, S.K. Effect of low protein diets and lysine supplementation on growth performance and carcass characteristics of growing pigs. Afr. J. Biotechnol. 2012, 11, 12128-12134. [CrossRef]

10. Wang, D.; Wan, X.; Peng, J.; Xiong, Q.; Niu, H.D.; Li, H.N.; Chai, J.; Jiang, S.W. The effects of reduced dietary protein level on amino acid transporters and mTOR signaling pathway in pigs. Biochem. Bioph. Res. Co. 2017, 485, 319-327. [CrossRef]

11. Chick, H.; Hume, E.M. The Production in Monkeys of Symptoms closely resembling those of Pellagra, by Prolonged Feeding on a Diet of Low Protein Content. Biochem. J. 1920, 14, 135-146. [CrossRef] [PubMed]

12. Metges, C.C.; Petzke, K.J.; El-khoury, A.E.; Henneman, L.; Young, V.R. Incorporation of urea and ammonia nitrogen into ileal and fecal microbial proteins and plasma free amino acids in normal men and ileostomates. Am. J. Clin. Nutr. 1999, 70, 1046-1058. [CrossRef] [PubMed]

13. Miner-williams, W.; Moughah, P.J.; Fuller, M.F. Endogenous Components of Digesta Protein from the Terminal Ileum of Pigs Fed a Casein-Based Diet. Agr. Food. Chem. 2009, 57, 2072-2078. [CrossRef] [PubMed]

14. Horwitz, W. Official Methods of Analysis of Association of Official Analytical Chemists International; Association of Official Analytical Chemists International: Rockville, MD, USA, 2000.

15. Moughan, P.J.; Hodgkinson, S.M. The enzyme hydrolysed protein method for the determination of endogenous ileal nitrogen and amino acid flows-a modification. Anim. Feed Sci. Tech. 2003, 108, 207-214. [CrossRef]

16. Zhao, L.; Guo, H.L.; Sun, H. Effects of low-protein diet supplementation with alpha etoglutarate on growth performance, nitrogen metabolism and mTOR signalling pathway of skeletal muscle in piglets. J. Anim. Physiol. An. N. 2020, 104, 300-309. [CrossRef]

17. Gloaguen, M.; Lefloc'h, N.; Corrent, E.; Primot, Y.; VanMilgen, J. The use of free amino acids allows formulating very low crude protein diets for piglets. J. Anim. Sci. 2014, 92, 637-644. [CrossRef]

18. Otto, E.R.; Yokoyama, M.; KU, P.K.; Ames, N.K.; Trottier, N.L. Nitrogen balance and ileal amino acid digestibility in growing pigs fed diets reduced in protein concentration. J. Anim. Sci. 2003, 81, 1743-1753. [CrossRef]

19. Portejoie, S.; Dourmad, J.-Y.; Martinez, J.; Lebreton, Y. Effect of lowering dietary crude protein on nitrogen excretion, manure composition and ammonia emission from fattening pigs. Livest. Prod. Sci. 2004, 91, 45-55. [CrossRef] 
20. Hansen, M.J.; Rgaard, J.V.N.; Adamsen, A.P.S.; Poulsen, H.D. Effect of reduced crude protein on ammonia, methane, and chemical odorants emitted from pig houses. Livest. Sci. 2014, 169, 118-124. [CrossRef]

21. Li, Y.K.; Lv, Z.Q.; Li, Z.C.; Liu, L.; Wang, F.L.; Li, D.F.; Lai, C.H. Effects of feeding level and dietary supplementation with crystalline amino acids on digestible, metabolizable and net energy values of corn in growing pigs. Anim. Feed Sci. Tech. 2018, 240, 197-205. [CrossRef]

22. Li, Y.H.; Wei, H.K.; Li, F.G.; Duan, Y.H.; Guo, Q.P.; Yin, Y.L. Effects of Low-Protein Diets Supplemented with Branched-Chain Amino Acid on Lipid Metabolism in White Adipose Tissue of Piglets. J. Agric. Food Chem. 2017, 65, 2839-2848. [CrossRef] [PubMed]

23. Hilliar, M.; Hargreave, G.; Girish, C.K.; Barekatain, R.; Swick, R.A. Using crystalline amino acids to supplement broiler chicken requirements in reduced protein diets. Poultry Sci. 2020, 99, 1551-1563. [CrossRef] [PubMed]

24. Isaacson, R.; Kim, H.B. The intestinal microbiome of the pig. Anim. Health Res. Rev. 2012, 13, 100-109. [CrossRef] [PubMed]

25. Świech, E.; Buraczewska, L.; Tusnio, A.; Taciak, M. The effects of supplementing a low-protein threonine-deficient diet with different sources of non-essential amino acids on nitrogen retention and gut structure in young pigs. Archiv. Für. Tierernaehrung. 2010, 64, 22-35. [CrossRef] [PubMed]

26. Goudoever, V.J.; Stoll, B.; Henry, J.F.; Burrin, D.G.; Reeds, P.J. Adaptive regulation of intestinal lysine metabolism. Proc. Natl. Acad. Sci. USA 2000, 97, 10620-10625. [CrossRef]

27. Metges, C.C. Contribution of Microbial Amino Acids to Amino Acid Homeostasis of the Host. J. Nutr. 2000, 130, 1857S-1864S. [CrossRef]

28. Torrallardona, D.; Hasrris, C.I.; Fuller, M.F. Lysine synthesized by the gastrointestinal microflora of pigs is absorbed, mostly in the small intestine. Ajp. Endocrinol. Metab. 2003, 284, E1177-E1180. [CrossRef]

29. Pi, Y.; Mu, C.L.; Gao, K.; Liu, Z.; Peng, Y.; Zhu, W.Y. Increasing the Hindgut Carbohydrate/Protein Ratio by Cecal Infusion of Corn Starch or Casein Hydrolysate Drives Gut Microbiota-Related Bile Acid Metabolism to Stimulate Colonic Barrier Function. Msystems 2020, 5, e00176. [CrossRef]

Publisher's Note: MDPI stays neutral with regard to jurisdictional claims in published maps and institutional affiliations.

(C) 2020 by the authors. Licensee MDPI, Basel, Switzerland. This article is an open access article distributed under the terms and conditions of the Creative Commons Attribution (CC BY) license (http://creativecommons.org/licenses/by/4.0/). 